\title{
A INTERTEXTUALIDADE E O DISCURSO RELIGIOSO NO CINDIR DO SUJEITO PERVERSO
}

\author{
Eugenia Adamy Basso ${ }^{79}$ \\ Claudia Lorena Fonseca ${ }^{80}$
}

Resumo: Este trabalho tem como objetivo realizar uma análise comparativa entre os discursos que constroem as personagens nas obras Lavoura Arcaica (1975, Brasil), de Raduan Nassar, e Do amor e outros demônios (1994, Colômbia), de Gabriel García Márquez, as quais apresentam traços de perversão, dentro de um contexto dominado por princípios religiosos. A metodologia parte da análise intertextual do discurso e do contexto que envolvem as personagens André e Ana (Lavoura Arcaica) e Cayetano e Sierva María (Do amor e outros demônios). A partir da análise desses discursos, trataremos de temas que se apresentam nas obras, e que se configuram como perversões: incesto e pedofilia, respectivamente, buscando os pressupostos da metalinguística bakhtiniana, bem como estudos de diferentes autores que abordam o tema da perversão, a fim de embasar nosso ponto de vista.

Palavras-chave: perversão; discurso; religião.

Abstract: This study has as objective the creation of a comparative analysis between the discourses that the characters develop in the novels Lavoura Arcaica (1975, Brazil), by Raduan Nassar, and Do amor e outros demônios (1994, Colombia), by Gabriel García Márquez, which present traces of perversion, in a context dominated by religious principles. The methodology starts from the intertextual analysis of the discourse and the context involving the characters André and Ana (Lavoura Arcaica) and Cayetano and Sierva María (Do amor e outros demônios). From the analysis of these discourses, we discuss about themes presented in the novels, configured as perversions: incest and pedophilia, respectively, seeking the

\footnotetext{
${ }^{79}$ Mestranda do Programa de Pós-graduação em Letras - Mestrado Acadêmico em Literatura Comparada da Universidade Federal de Pelotas - UFPel. Bolsista CAPES.

${ }^{80}$ Doutora em Literatura Comparada. Professora Adjunta do Centro de Letras e Comunicação e do Programa de Pós-graduação em Letras da Universidade Federal de Pelotas - UFPel.
} 
254 | Eugenia Adamy Basso e Claudia Lorena Fonseca

presuppositions of Bakhtinian metalinguistics, as well as studies of different authors who approach the subject of perversion, in order to base our point of view.

Keywords: perversion; discourse; religion.

\section{Considerações iniciais}

O conceito da perversão pode ser resumidamente definido, dentre seus múltiplos entendimentos, como um comportamento inadequado social e moralmente, em que o indivíduo busca a satisfação de seus desejos (geralmente sexuais), desconsiderando a alteridade. Trata-se de uma perturbação de ordem psíquica. Ferraz (2010) menciona que "basta dizer-se perversão para imaginarmos algum desvio na vida sexual” (p. 22). Quando o indivíduo é perverso, ele faz questão de desafiar tais convenções sociais e morais; porém, aparentemente, parece ter uma vida completamente normal, com um discurso convincente, sem que as pessoas percebam suas intenções.

$\mathrm{Na}$ literatura, muitas obras tratam do tema, a partir da forma como se apresentam suas personagens, seja no que diz respeito ao seu comportamento, ou de como se configuram psicologicamente. Inclusive, obras famosas foram utilizadas na psicanálise para nomear algumas perversões - como é o caso dos clássicos A Vênus das peles, de Leopold von Sacher-Masoch (século XIX), 120 dias de Sodoma (século XVIII), do Marquês de Sade, as quais dão nome aos desvios sexuais masoquismo e sadismo, respectivamente. Outra obra literária a se considerar, nesse caso, é Lolita, de Vladimir Nabokov, publicada já no século passado, a qual dá ensejo à discussão sobre outro desvio sexual: a pedofilia. Em algumas obras, o discurso do indivíduo perverso se apresenta claro e objetivo; porém, em outras, o discurso se apresenta de forma a que se configure como ambíguo e mesmo lírico, muitas vezes levando o leitor a crer que as relações que se dão entre as personagens são relações de afeto ou, mais especificamente, relações de amor.

Nesse sentido, o objetivo deste estudo é realizar uma análise comparativa entre os discursos que constroem as personagens nas obras Lavoura Arcaica (1975, Brasil), de Raduan Nassar, e Do amor e outros demônios (1994, Colômbia), de Gabriel García Márquez, personagens que apresentam traços de perversão, dentro de um contexto dominado por princípios religiosos e moralistas. 


\section{Contextos diferentes, mas com muito em comum}

A narrativa de Raduan Nassar, Lavoura arcaica, trata de uma família de descendência libanesa, moradores da zona rural, que vivem da lavoura e da criação de animais. A família é extensa - o pai, a mãe, os irmãos: Lula, Rosa, Zuleika, Huda, Pedro, André e Ana - e vive em um modelo considerado arcaico para a época: a lida no campo, o trato com os animais, as refeições (com todos juntos e sentados nos mesmos lugares à mesa) acompanhadas de sermões religiosos e morais, a união, o pudor e o recato extremo. O pão feito em casa, o vinho, as preces e a lida são elementos primordiais que devem compor o dia a dia familiar e seus integrantes devem estar sempre em completa união um com o outro. Este ambiente é bem diferente do encontrado na narrativa de García Márquez, a qual se passa dois séculos antes.

Do amor e outros demônios ambienta-se na Colômbia, quando ainda colônia espanhola. Uma menina, Sierva María de Todos los Ángeles, filha de um marquês, mas que convive com os escravos de sua casa e assimila sua cultura e religião, é mordida por um cachorro de rua e é contaminada com a doença da raiva. Após esse acontecimento e inúmeras tentativas de tratamento médico, Sierva María é enviada para um convento, com a alegação de estar possuída pelo demônio. Lá, a menina conhece o padre espanhol Cayetano Delaura, incumbido de ajudá-la no processo de exorcismo.

Contextos distintos, mas com situações em comum. O fato é que ambas as obras apresentam, na relação entre suas personagens, traços que revelam comportamentos sexuais tidos como inadequados ou imorais, independente de serem tratadas, em uma leitura menos atenta, como relações amorosas. Na primeira, o foco é a relação incestuosa entre André e Ana, que acaba por abalar totalmente a estrutura familiar - além de outras ocorrências envolvendo o tema da perversão. Na segunda, o padre Cayetano se relaciona com uma menina de doze anos de idade, Sierva María, que está presa e acorrentada em uma cela, sempre a receber suas visitas, a princípio contra sua vontade - uma atitude que, somada a outros indícios, faz com que possamos aventar a possibilidade de tratar-se, nesse caso, de uma relação pedófila.

As personagens perversas, no caso André e Cayetano, apresentam as características do que se define como perversão: 
É igualmente notável que existam pessoas cujos desejos se comportem exatamente como os sexuais, mas que ao mesmo tempo prescindam inteiramente dos órgãos sexuais ou de seu uso normal; tais seres humanos são chamados de perversos (FREUD, 2014, p. 40).

De acordo com a psicanálise, o indivíduo está exposto, desde sua infância, a processos de castração. Estas ocorrências permitem que surjam lacunas que, mais tarde, acabam sendo preenchidas por determinados transtornos:

A sexualidade normal dos adultos surge da sexualidade infantil através de uma série de desenvolvimentos, combinações divisões e repressões que dificilmente se completam com perfeição ideal, deixando consequentemente em seu rastro predisposições a uma regressão da função, sob a forma de doença (FREUD, 1990, p. 126)

O indivíduo perverso dificilmente é percebido como tal quando em convívio com a sociedade, sendo sua postura bastante convincente e seu discurso altamente manipulador. Na busca da satisfação de seus desejos, ele entra em situação de transtorno e desespero, tentando alcançar o prazer de qualquer modo. Acredita-se que as pessoas que apresentam tais traços não perdem totalmente o contato com a realidade, tendo noção do que é certo e errado; pois, ao agir, elas procuram fazer isso longe dos olhos dos demais, burlando as normas morais de convívio. O prazer próprio é sempre prioridade.

Nesse sentido, as personagens de traços perversos, André e Cayetano, buscam o próprio prazer tentando não chamar a atenção ao seu redor. Além disso, utilizam uma técnica na aproximação de suas vítimas, fundada em um discurso de sedução e conquista. Ao tentar se eximir de suas culpas, justificam que sua relação é amor ou, então, culpam as vítimas, as quais, nas obras em questão, são comparadas com o demoníaco, segundo uma concepção religiosa. Ambas as personagens estão inseridas em um contexto em que a religião está fortemente presente, castrando seus desejos e, assim, os sujeitos se dividem entre a culpa de sua imoralidade e a satisfação de sua natureza: para isso, a única saída é utilizar o discurso para fugir de sua responsabilidade. Neste caso, podemos constatar a existência de um diálogo entre as duas obras. 
O texto aparece então como o lugar de uma troca entre pedaços de enunciados que ele redistribui ou permuta, construindo um texto novo a partir dos textos anteriores. Não se trata, a partir daí, de determinar um intertexto qualquer, já que tudo se torna intertextual; trata-se de trabalhar sobre a carga dialógica das palavras e dos textos, os fragmentos de discursos que cada um deles introduz no diálogo (SAMOUYAULT, 2008, p. 18).

Segundo Mikhail Bakhtin (2002), a língua, ao contrário do que os estruturalistas afirmavam, não é uma forma, mas sim, um sistema que está sempre em ação, um organismo vivo. O discurso jamais será algo individual, pois sempre envolverá, no mínimo, duas posições, aquele que enuncia e seu interlocutor.

$\mathrm{Na}$ esteira dos estudos de Bakhtin, estão os de Júlia Kristeva, a qual partindo da noção de dialogismo e ampliando-a, sistematiza e nomeia o fenômeno da intertextualidade. Para a autora, o discurso literário dialoga com várias outras escrituras e, para que ocorra o fenômeno da intertextualidade, é importante que o leitor reconheça a presença de outros textos em relação com o que está lendo.

[...] a palavra (o texto) é um cruzamento de palavras (textos) onde se lê, pelo menos, uma outra palavra (texto). Segundo Kristeva, Bakhtin não distingue claramente esses dois eixos, mas esta falta de rigor não minimiza uma importante descoberta para a teoria literária: "todo texto se constrói como mosaico de citações, todo texto é absorção e transformação de um outro texto. Em lugar da noção de intersubjetividade, instala-se o da intertextualidade e a linguagem poética lê-se, pelo menos, como dupla”. Neste momento, Kristeva elabora o já famoso conceito de intertextualidade (NITRINI, 2010, p. 161).

Seguindo nesta linha argumentativa, entende-se que o texto carrega, consigo, os reflexos de uma memória literária, em que nada é original, nada é completamente autêntico: sempre haverá um diálogo com um texto anterior. 
O livro remete a outros livros e, pelo processo de somação, confere a esses livros um novo modo de ser, elaborando assim a sua própria significação. Nessa perspectiva, o texto literário se apresenta como um sistema de conexões múltiplas, que poderíamos descrever como uma estrutura de redes pragmáticas (NITRINI, 2010, p. 163).

No que diz respeito à memória da literatura, deve-se levar em conta que o texto estará impregnado da biblioteca de quem o produz, o que, posteriormente, acionará a biblioteca do leitor. Tiphaine Samouyault afirma que

a literatura se escreve com a lembrança daquilo que é, daquilo que foi. Ela a exprime, movimentando sua memória e a inscrevendo nos textos por meio de um certo número de procedimentos de retomadas, de lembranças e de re-escrituras, cujo trabalho faz aparecer o intertexto. Ela mostra assim sua capacidade de se constituir em suma ou em biblioteca e de sugerir o imaginário que ela própria tem de si. Fazendo da intertextualidade a memória da literatura, propõe-se uma poética inseparável da hermenêutica: trata-se de ver e de compreender do que ela procede, sem separar esse aspecto das modalidades concretas de sua inscrição (2008, p. 47).

Ao colocar em contraste duas obras literárias, estabelecemos semelhanças e divergências entre elas, seja no conteúdo abordado, seja no estilo de escrita, na construção das personagens e da narrativa, ou na forma como se apresenta o texto. Considerando-se esses aspectos, partimos, então, para a análise do diálogo entre as duas obras em destaque neste estudo.

\section{A abordagem do perverso - o discurso sedutor}

André e Ana. Dois irmãos que, a princípio, são apaixonados um pelo outro, se levamos em conta o discurso de André. Narrado em primeira pessoa, todas as situações apresentadas no romance passam, primeiramente, pelo seu olhar: "O narrador, personagem central, não tem acesso ao estado mental das demais personagens. Narra de um centro fixo, limitado quase que exclusivamente às suas percepções, pensamentos 
A intertextualidade e o discurso religioso no cindir do sujeito perverso | 259

e sentimentos" (CHIAPPINI, 1985, p. 44). O que se sabe da arcaica família, da mãe e suas culpas, da irmã e sua peçonha, e toda a informação a que temos acesso, nos é disponibilizado pelo narrador, o irmão fugido, o membro da família que não se enquadra no contexto em que se via obrigado a viver, retrógrado e sufocante para ele. $\mathrm{O}$ mesmo podemos afirmar sobre o relacionamento entre ele e a irmã - Ana é construída pelo seu discurso. Suas atitudes, a paixão, tudo é efeito do que André acredita ou quer fazer acreditar que seja - a subjetividade é extrema.

André busca levar seu interlocutor a acreditar que desde cedo é influenciado pela irmã, que a cumplicidade entre eles vai além do fraterno. Além disso, esse contato é descrito como alegre, envolvendo sentimentos amorosos, principalmente vindos de Ana. Porém, mais adiante, conforme André conversa com seu irmão Pedro e confessa sua aflição, ele sutilmente, em seu discurso lírico e romantizado, deixa que se torne visível outra face de seu eu, manipulador e possessivo. Como ele mesmo afirma, o sentimento que antes lhe parecia alegre, na verdade lhe traz prejuízos: "o mundo das paixões é o mundo do desequilíbrio, é contra ele que devemos esticar o arame das nossas cercas" (p. 56). Há portanto uma contradição na história que conta.

No que diz respeito a outra obra que analisamos, Do amor e outros demônios, constatamos que esta apresenta um ponto de vista distinto: o narrador em terceira pessoa, onisciente, e as personagens protagonistas, Cayetano e Sierva María, apresentadas pelo discurso do narrador, ou eventualmente em voz direta, por meio de diálogos, nos quais sobressai o ponto de vista de Cayetano:

Ao terminar o exame, Delaura mandou buscar um estojo de curativos, mas barrou a entrada da irmã enfermeira. Untou as feridas com bálsamos e aliviou com sopros suaves a ardência da carne viva, admirado da resistência da menina à dor. Sierva María não respondeu a nenhuma de suas perguntas, não se interessou por suas prédicas nem se queixou de nada. Foi um começo desanimador, que perseguiu Delaura até o remanso da biblioteca (MÁRQUEZ, 1996, p. 124-125).

A opção pelo narrador heterodiegético, torna mais complexa a situação narrativa, ao constatarmos a presença do discurso indireto livre, mesclando a voz do narrador à voz das personagens, seletivamente. No trecho acima, percebe-se que Delaura já tem sua primeira impressão 
acerca da menina, por meio de seu primeiro contato físico com ela, além de se sentir tomado pela desesperança em relação ao caso de Sierva María. Observamos que não temos acesso aos sentimentos da menina, pois o foco está, preferencialmente, em Delaura, configurando-se assim, um caso de onisciência seletiva, considerando-se a tipologia de Norman Friedman para a categoria do narrador, sistematizada por Lígia Chiappini (1985, p. 54), que afirma que nesta categoria, assim como na categoria do narrador protagonista, "o ângulo é central, e os canais são limitados aos sentimentos, pensamentos e percepções da personagem central, sendo mostrados diretamente". Nesse sentido, a quem é dado o direito de se manifestar em voz narrativa não é a menina, mas sim o padre. A menina é apresentada apenas como a causa dos diversos problemas que ocorrem no convento, o que faz com que ocupe, também ela, posição central na narrativa. Sem direito à voz, adquire complexidade ainda maior, dado o fato de que é necessário que também nós nos empenhemos em decifrá-la.

Seguindo nesta linha argumentativa, percebe-se que em ambas as obras há a opção de dar voz narrativa às personagens que apresentam traços que as vinculam a perversões, privilegiando seu ponto de vista. $\mathrm{O}$ leitor acaba por não ter acesso à voz de nenhuma daquelas que seriam suas vítimas. O que chega ao leitor são as ações, a maneira pela qual a personagem perversa se aproxima dessas vítimas, configurando-se nesse caso um discurso convincente, de quem parece nunca ter culpa de suas ações - princípio fundamental do perverso, que é o de exercer a sua natureza a qualquer custo, atribuindo, para isso, a responsabilidade a qualquer outra pessoa.

O discurso de André é, portanto, bastante convincente, utilizando de muitas metáforas para fazer com que seu interlocutor acredite que seus instintos fora de controle nada mais são do que amor: "e as pombas do meu quintal eram livres de voar, partiam para longos passeios mas voltavam sempre, pois não era mais do que amor o que eu tinha e o que eu queria delas" (p. 98, grifo nosso). Nesta passagem, em que ele compara Ana com as pombas da fazenda, que ele capturava com arapucas, André busca alimentar a ideia de que sua relação incestuosa com a irmã não a aprisionava, que era natural, uma relação saudável de liberdade. Posteriormente, em contrapartida, no decorrer de seu discurso, André se contradiz:

grão por grão, instante por instante, mais manhosa era a pomba quanto mais próxima da peneira, bicando o chão com firmeza, mas tremendo antes o pescoço, como o braço 
A intertextualidade e o discurso religioso no cindir do sujeito perverso | 261

de um monjolo sempre indeciso a meio caminho do seu destino [...] ameaçando as penas em recuo, até que, transpondo o arco da peneira, um doce alimento faria esquecer, projetada na terra, a grade da sua tela; era uma ciência de menino, mas era uma ciência complicada, nenhum grão de mais, nenhum instante de menos, para que a ave não encontrasse o desanimo na carência nem na fartura, existia a medida sagaz, precisa, capaz de reter a pomba confiante no centro da armadilha (p. 100).

Na passagem acima, André deixa evidente sua estratégia: aproximase aos poucos da vítima, ganhando sua confiança, oferecendo-lhe uma recompensa a cada passo em sua direção. Como ele mesmo afirma, tratase de uma armadilha, o que desmancha a tese de que é amor. André tem conhecimento de que o que ele faz é considerado imoral e que, para isso, terá que usar de artimanhas para seduzir a irmã. $O$ mesmo ocorre no discurso sedutor de Cayetano, que sabe que a menina com quem ele se envolve é uma criança, e que é inadequado relacionar-se intimamente com ela, somado ao fato de que ele é um padre, indo assim contra os princípios que regem sua opção de vida, os quais, segundo se observa, Cayetano a principio respeita.

Cayetano, meio de brincadeira e meio a sério, se atreveu a soltar o cordão do espartilho de Sierva María. Ela protegeu o peito com as duas mãos; houve uma chispa de raiva em seus olhos e uma rajada de rubor the incendiou o rosto. Cayetano lhe agarrou as mãos com o polegar e o indicador, como se estivessem em fogo vivo, e as afastou do peito. Ela tentou resistir, e ele lhe opôs uma força terna mas resoluta. - Repete comigo - disse: - "Enfim, a vossas mãos hei chegado." Ela obedeceu. - "Onde sei que hei de morrer" prosseguiu ele, enquanto abria o espartilho com seus dedos gelados. Ela repetiu quase sem voz, trêmula de medo [...] (MÁRQUEZ, 1996, p. 190-191, grifos do autor).

Neste trecho, em um dos encontros entre Cayetano e Sierva María, o narrador abre espaço para o diálogo direto das personagens, afastando-se. É notável que Cayetano utiliza, além da força física, um discurso sedutor e romântico para atrair a menina, fazendo com que ela repita os versos que ele recita. Ele manipula Sierva María, fazendo com 
262 | Eugenia Adamy Basso e Claudia Lorena Fonseca

que ela afirme que, uma vez pertencendo a ele, assim permanecerá até o dia de sua morte.

$\mathrm{O}$ ato da conquista é comum no comportamento de pessoas perversas. Em seus estudos sobre perversão, Ferraz (2010) relata e analisa casos de pacientes perversos, comparando-os com personagens icônicos da literatura:

A hostilidade tem o propósito de fazer com que o sujeito se sinta superior e triunfante sobre o outro. Se nas práticas sexuais sádicas isto é evidente por si só, em outras variantes da perversão, no entanto, tal asserção não é facilmente visível. Stoller explica sob esse prisma, por exemplo, a promiscuidade comum na dinâmica da perversão: ela seria uma resultante da hostilidade, visto que o interesse do perverso encontra-se na sedução e não no amor. É assim que, em Don Juan, a gratificação não provém do prazer do ato sexual ou da intimidade estabelecida com outra pessoa, mas exclusivamente do ato de sedução (p. 84-85).

Como é possivel perceber, a prática da sedução é forma de prazer, que provém da castração, em que o proibido provoca o desejo. A conquista final da vítima será sempre o prêmio a ser arrebatado, o que faz parte do universo do perverso, que nas obras em destaque neste artigo também envolvem uma proibição maior, sobre a qual tratamos a seguir.

\section{A natureza perversa e a religião}

O vínculo com a religiosidade, mais especificamente com os dogmas da religião católica, faz-se tão presente nas obras Lavoura Arcaica e Do amor e outros demônios que é possível afirmar que compõe sua temática central. Ambas apresentam a religião como um impedimento para que os instintos das personagens André e Cayetano sejam externalizados; sendo então instituição reguladora que reprime suas vontades, caracterizando-as como imorais. A família de André é descendente de libaneses que vieram para o Brasil, portanto, há certa mescla de princípios entre a religião cristã e a religião muçulmana, o que pode ser percebido, por exemplo, quando Ana se dirige à capela para rezar, quando seria de se esperar uma pequena mesquita e, também, no consumo e na ostentação do vinho. No entanto, algumas características se mantêm fortes: os sermões, as festas e as danças. 
A intertextualidade e o discurso religioso no cindir do sujeito perverso | 263

No decorrer da narrativa de André, a religião é apresentada como um fator que o indigna sobremaneira, um empecilho para a realização de seu amor com a irmã. A religião é o que une e estrutura a família, instituição que possui regras de convivência, e na qual André não consegue se inserir, sendo visto como um ser de conduta abjeta aos olhos dos demais. Sobre a abjeção, observa Julia Kristeva que, "del objeto, lo abyecto no tiene más que una cualidad, la de oponerse a yo [...] Está afuera, afuera del conjunto cuyas regras del juego parece no reconocer" (2004, p. 8) - ou seja, o abjeto não se enquadra em um padrão de normas de convívio estabelecidas, sendo isolado e visto como repulsivo:

E me lembrei que a gente sempre ouvia nos sermões do pai que os olhos são a candeia do corpo, e que se eles eram bons é porque o corpo tinha luz, e se os olhos não eram limpos é que eles revelavam um corpo tenebroso, e eu ali, diante de meu irmão, respirando um cheiro exaltado de vinho, sabia que meus olhos eram dois caroços repulsivos [...] (NASSAR, 1999, p. 15).

Com relação a Delaura, percebe-se que, até a chegada de Sierva María ao convento, a personagem estava bem adaptada ao contexto em que vivia. Estudou Teologia na cidade de Salamanca, bem orientado pelo bispo De Cáceres y Virtudes. Com vinte e três anos, descobre que sua vocação era seguir o caminho do Espírito Santo: "- Se Deus me concedesse a graça, eu não queria ser santo, e sim anjo” (MÁRQUEZ, 1996, p. 117). Ao ser chamado ao convento de Santa Clara, a fim de exorcizar Sierva María, conhece as pessoas que foram orientadas a mediar sua relação com a menina, como a abadessa do local. Logo que é levado a conhecer os espaços do convento, percebe que este apresenta uma atmosfera pesada, com odores fétidos, animais barulhentos e que supostamente falavam. Para justificar tais acontecimentos, a abadessa afirma que tudo estava nesse estado devido à presença de Sierva María, que era comparada com o demônio: "Tudo anda assim desde que o seu bispo fez o favor de nos mandar esse presente envenenado" (p. 119). No entanto, Cayetano, mesmo antes de conhecer a menina, não acreditava que pudesse ser algo assim tão grave. Ao chegar a sua cela e observar o espaço de seu cárcere, Delaura afirma, surpreso: “- Mesmo que não estivesse possuída por nenhum demônio - disse -, esta pobre criança tem aqui o ambiente mais propício para ficar possuída" (p. 122). É a conclusão a que chega o padre ao ver que a menina vivia em condições subumanas de higiene. Ao 
264 | Eugenia Adamy Basso e Claudia Lorena Fonseca

acreditar que o problema não está localizado totalmente na criança e que o ambiente em que ela está vivendo então não é digno, Delaura se posiciona criticamente em relação ao ponto de vista dominante sobre a situação de Sierva María, tendo início, assim, um processo de descrédito de Cayetano para com o que até então norteava suas ações, abrindo espaço para a subversão da norma.

Percebe-se, a partir das breves descrições do contexto em que se inserem André e Cayetano, que estas personagens se encontram em um espaço em que a moral religiosa está fortemente presente, e que seus desejos não poderiam ser sempre realizados. $O$ interlocutor, em uma primeira leitura, poderia afirmar que tais personagens estão vivendo um amor impossível o que não se confirma nos fatos e no seu discurso.

A pulsão tem sua origem no corpo e sua ligação com a
esfera psíquica é feita pelos representantes pulsionais: o
afeto e a representação. O afeto é, assim, um representante
pulsional, que, ao lado da representação, intermedia o
acesso da pulsão à esfera psíquica, já que a primeira tem
sua fonte no corpo. Para Freud, o afeto é uma energia,
enquanto que a representação é uma ideia (MARQUES,
2012, p. 47).

Nesse sentido, é importante observar que estas personagens encontram na proibição uma impossibilidade de exercer seu desejo, baseado na pura energia de suas pulsões. É necessário entender que isso não deve ser confundido com amor pois, apesar de lançarem mão de um discurso romântico e convincente, em suas contradições, abordagens narrativas e entrelinhas, percebemos que Cayetano e André buscam apenas a satisfação de seus instintos, além da posse de seu objeto de desejo.

No que concerne às questões de natureza religiosa, um importante fator interfere ainda na vida de André, a figura de seu pai, que diariamente realiza sermões moralizantes durante as refeições em família, os quais consistem em textos que mesclam tanto trechos da Bíblia quanto do Alcorão. Estes discursos abordam a ordem familiar, o trabalho, a paciência, configurando-se em discursos que disseminam valores com forte marca ideológica, e que beiram o autoritarismo.

[...] rico só é o homem que aprendeu, piedoso e humilde, a conviver com o tempo, aproximando-se dele com ternura, 
A intertextualidade e o discurso religioso no cindir do sujeito perverso | 265

não contrariando suas disposições, não se rebelando contra o seu curso, não irritando sua corrente, estando atento para o seu fluxo, brindando-o antes com sabedoria para receber dele os favores e não a sua ira (NASSAR, 1999, p. 54).

Evidencia-se, no trecho acima, que a resignação é um dos temas do sermão. $\mathrm{O}$ respeito e a submissão ao tempo é um dos valores essenciais a serem cultivados pelo homem, que deve deixar sob seu comando as situações que aparecem, além de mostrar a ele os caminhos a serem tomados. Aqueles que convivem na família devem apenas aguardar a ação do tempo, respeitosos.

Outro importante marco religioso que encontramos na narrativa é a parábola do faminto, na qual um homem, com muita fome, chega até o palácio de um homem muito poderoso, que lhe oferece um banquete de comida invisível, mesmo havendo comida real no castelo. Ao retomar essa parábola, que era contada pelo seu pai, André comenta: "Como podia o homem que tem o pai na mesa, o sal para salgar, a carne e o vinho, contar a história de um faminto?" (p. 86) - ou seja, para ele, o pai, apesar de se mostrar uma figura sábia e solidária, negava ao faminto (aqui, no caso, André) o que ele realmente precisava: a liberdade e o livre exercício da libido.

Além da questão religiosa e moral do pai, André identifica ainda o que ele considera a origem dos problemas da família, analisando a posição em que os integrantes se sentam à mesa no momento das refeições, posições que são fixas:

O galho da direita era um desenvolvimento espontâneo do tronco, desde as raízes; já o da esquerda trazia o estigma de uma cicatriz, como se a mãe, que era por onde começava o segundo galho, fosse uma anomalia, uma protuberância mórbida, um enxerto junto ao tronco talvez funesto, pela carga de afeto; podia-se quem sabe dizer que a distribuição dos lugares à mesa (eram caprichos do tempo) definia as duas linhas da família (p. 157).

Pode-se notar que a distribuição dos lugares designados aos membros da família nas refeições também deixavam André em situação de conflito: sua mãe, cuja figura no decorrer da trama também aparece erotizada em seu discurso, é, segundo ele, um dos motivos do fracasso da estrutura familiar. 
Na obra de Raduan Nassar, há a completa submissão de uma família a um sistema religioso e moral. $\mathrm{O}$ mesmo ocorre na história de García Márquez, de forma ainda mais evidente, ao centrar o conflito na figura de um padre, que escolheu a religião católica para exercer sua vocação. Cayetano Delaura vive para servir incondicionalmente a Deus. No contexto da obra, a religião católica define o comportamento moral da sociedade, que vive em alienação total. Segundo Hegel, a alienação dos indivíduos é a opressão na qual o homem está em uma situação de completa dependência de um Deus dominante, sentindo-se obrigado a obedecer a Ele a todo instante (ZILLES, 2001). São esses princípios que norteiam e condicionam a vida no Convento que passa a frequentar Delaura em função de seu trabalho e assim é também no seu local de trabalho original. A cisão que se opera na personagem ocorre quando o conflito entre seus princípios e suas pulsões se estabelece.

Poder-se-á perguntar até que ponto a distância de Deus ou de sua ausência não expressam a auto-reclusão do homem. A fé, como fundamento da religião, constitui também ato íntegro e totalmente humano. Tem que se reconhecer como humanamente cheia de sentido e intelectualmente honesta e responsável (ZILLES, 2001, p. 15).

Quando Delaura se afasta de Deus para viver sua relação com a menina, percebe-se o quanto ele está prisioneiro de um sistema religioso que castra (ou tenta castrar) sua sexualidade. A própria personagem escolheu o seu destino de encarcerado, punindo-se ao admitir que pecava por agir libidinosamente.

Abriu a maleta de Sierva María e pôs as coisas uma a uma
em cima da mesa. Conheceu-as, cheirou-as com um desejo
ávido do corpo; amou-as e falou com elas em hexâmetros
obscenos, até que não pôde mais. Então desnudou o torso,
tirou da gaveta da mesa de trabalho a disciplina de ferro
que nunca ousara tocar e começou a flagelar-se com um
ódio insaciável, que não lhe daria trégua até extirpar de
suas entranhas o último vestígio de Sierva María. O bispo,
que tinha ficado à espera dele, encontro-o revolvendo-se
num lamaçal de sangue e lágrimas. - É o demônio, meu pai
- disse Delaura. - O mais terrível de todos (MÁRQUEZ,
1996, p. 177). 
Observamos que a personagem tem, nesse momento, plena consciência de seus sentimentos - ou de seus desejos - e da impossibilidade de controlá-los, dada a sua natureza. O bispo, que o acompanha na missão de exorcismo de Sierva María, também percebe o que ocorre. $\mathrm{O}$ padre não consegue se conter e, ao perceber isso, não assume a responsabilidade de suas pulsões, colocando a culpa no demônio - que, na obra, por meio de seu discurso e do narrador, estaria representado pela menina.

Sierva María de Todos los Ángeles nunca teve a atenção necessária de seus pais. Após ter sido mordida por um cão raivoso, sua mãe, Bernarda, afirma ao marido: “- o cachorro é que morreu por tê-la mordido" (p. 26), dando a entender que a menina é portadora de algo maligno. A falta de afeto dos pais pela menina é evidente.

Ambos continuaram atentos aos rumores crescentes sobre a gravidade da peste, e embora a contragosto tiveram que conversar outra vez sobre assuntos que lhes eram comuns, como no tempo em que se odiavam menos. Para ele era claro. Sempre acreditou que amava a filha, mas o medo do mal de raiva o obrigava a confessar que se enganava a si mesmo por uma questão de simples comodismo. Já Bernarda nem sequer se interrogou, porque tinha plena consciência de que não a amava e nem era amada por ela, e ambas as coisas lhe pareciam justas (p. 27).

Devido a tais circunstâncias, a menina termina por ser criada pelos escravos da casa, principalmente por Dominga de Adviento, que governava a casa e estabelecia a ligação de Sierva María entre o mundo cristão dos brancos e o mundo da senzala, com a religião africana. Após a morte da governanta, os ambientes da casa sofrem com o descaso, o que dá ensejo à falta de controle generalizada e as consequências que isso acarreta: a desordem nas barracas dos escravos e todo um cenário que é o retrato do grotesco e da indignidade humana: pessoas relacionando-se sexualmente em todos os ambientes, de forma ostensiva muitas vezes, outras estiradas pelos cantos, ou raspando restos de comidas das panelas, jogos tradicionais nos corredores, entre outras práticas e situações. Ali, Sierva María é criada e ali, por exemplo, festeja todos seus aniversários: 
A menina se mostrava tal como era. Dançava com mais graça e donaire que os africanos da nação, cantava com vozes diferentes da sua nas diversas línguas da África, ou com vozes de pássaros e animais, que desconcertavam os próprios negros. Por ordem de Dominga de Adviento, as escravas mais jovens pintavam-lhe a cara com fuligem, penduravam colares de candomblé por cima do escapulário do batismo e ajeitavam-lhe o cabelo, jamais cortado, que atrapalharia o caminhar não fossem as tranças de muitas voltas que lhe faziam todo dia (p. 21).

Sierva María nasceu prematura, com saúde frágil, e a parteira logo informou à criada Dominga de Adviento que a menina não sobreviveria. Rejeitada pelos pais, a menina foi batizada por Dominga no cristianismo e também na religião ioruba, sendo dedicada à divindade Olokun "[...] de sexo incerto, cujo rosto se presume tão temível que só se deixa ver em sonhos, e sempre de máscara" (p. 66). Não somos informados da razão pela qual Dominga de Adviento consagra a menina a essa divindade, especificamente, apenas se estabelece a relação de Sierva María com o rosto obscuro e amedrontador dessa entidade, o que lhe confere mais uma característica negativa. Segundo Mason (1996), desde sempre Olokun simbolizou a justificativa de esperança, e que muitos dos iorubás que sobreviveram à terrível "Passagem do Meio" (migração de africanos para a América) fizeram de Olokun e Iemanjá símbolos de renascimento. Para eles, Olokun auxilia na prosperidade dos africanos na América, ajudando, também, a conectá-los a sua espiritualidade. Tais aspectos místicos não são abordados na obra, fazendo com que a obscuridade dessa divindade seja transmitida e associada à Sierva María como algo assustador, e não o que seria de fato, ou seja, um orixá cultuado e importante para os africanos escravizados.

Por ter, desde a primeira infância, contato com uma religião distinta daquela que regia a vida dos burgueses e dos nobres da Colômbia - o catolicismo, o comportamento de Sierva María contrastava com o de sua classe, era diferente, pois trazia os traços culturais africanos.

Segundo a prática comprovada, consideram-se como sinais de possessão do demônio: dizer muitas palavras de língua desconhecida ou entender quem assim fala; revelar coisas distantes e ocultas; manifestar forças acima da sua idade ou condição natural. Estes sinais podem fornecer algum 
A intertextualidade e o discurso religioso no cindir do sujeito perverso | 269 indício. Como, porém, os sinais deste género não são necessariamente atribuíveis à intervenção do diabo, convém atender também a outros, sobretudo de ordem moral e espiritual, que manifestam de outro modo a intervenção diabólica, como p. ex. a aversão veemente a Deus, ao Santíssimo Nome de Jesus, à Bem-aventurada Virgem Maria e aos Santos, à Igreja, à palavra de Deus, a objetos e ritos, especialmente sacramentais, e às imagens sagradas. Finalmente, por vezes é preciso ponderar bem a relação de todos os sinais com a fé e o combate espiritual na vida cristã, porque o Maligno é principalmente inimigo de Deus e de tudo o que relaciona os fiéis com a ação salvífica (CONFERÊNCIA EPISCOPAL PORTUGUESA, p. 16).

Sendo assim, seu comportamento era associado ao demônio, o que se intensifica logo após a mordida do cão raivoso. A religião define cada uma das personagens, pois,

no fundo de toda a situação verdadeiramente religiosa encontra-se a referência aos fundamentos últimos do homem: quanto à origem, quanto ao fim e quanto à profundidade. $\mathrm{O}$ problema religioso toca o homem em sua raiz ontológica. Não se trata de fenômeno superficial, mas implica a pessoa como um todo. Pode caracterizar-se o religioso como zona do sentido da pessoa. Em outras palavras, a religião tem a ver com o sentido último da pessoa, da história e do mundo (ZILLES, 2010, p. 6).

Nas duas obras com as quais trabalhamos neste estudo, pela situação de discurso que se apresenta, as personagens que são vítimas de sujeitos que se caracterizam por seus traços perversos são responsabilizadas pelos acontecimentos trágicos ocorridos, por supostamente carregarem em si traços demoníacos, apesar de não possuírem voz dentro das narrativas e serem descritas sempre por outra voz, responsável por mediar o contato entre a personagem e o leitor. André, por exemplo, desde o início descreve sua irmã como uma figura traiçoeira, que, segundo ele, "trazia a peste no corpo": 
[...] e magnetizando a todos, ela roubava de repente o lenço branco do bolso de um dos moços, desfraldando-o com a mão erguida acima da cabeça enquanto serpenteava o corpo, ela sabia fazer as coisas, essa minha irmã, esconder primeiro bem escondido sob a língua a sua peçonha e logo morder o cacho de uva que pendia em bagos túmidos de saliva enquanto dançava no centro de todos, fazendo a vida mais turbulenta, tumultuando dores, arrancando gritos de exaltação [...] (NASSAR, 1999, p. 31).

O trecho acima apresenta a visão de André enquanto observa sua irmã dançando durante uma das festas da família, na qual os amigos se faziam presentes. Percebe-se que os movimentos de Ana durante a dança são relacionados aos de uma serpente quando rasteja e se eleva, além de trazer o veneno transportado pelas presas. Em nenhum momento o leitor é informado sobre o que ela pensa ou sente ao dançar, e se realmente os movimentos correspondiam à descrição do narrador protagonista André jamais lhe passa a palavra no transcorrer da narração. Ana é constantemente relacionada ao pecado e à serpente - primeiro animal a levar o Homem à tentação. No entanto, após o retorno de André para a família, é na capela que Ana busca refúgio, e lá permanece na quase totalidade de seu tempo, ignorando-o, sem responder aos seus lamentos e a sua chantagem emocional. Percebe-se que André sabe que seus desejos não podem ser realizados, pois o ambiente em que ele e a irmã vivem não o permite, a criação que receberam condena o incesto; por esse motivo, ele teria deixado a casa, para supostamente tentar lutar contra este conflito.

Em um de seus momentos de desespero, André conversa com Deus, pedindo para que Ele o libere para viver seu romance com Ana:

[...] meu Deus, eu pedia, um milagre e eu na minha descrença te devolvo a existência, me concede viver esta paixão singular, fui suplicando enquanto a polpa feroz dos meus dedos tentava revitalizar a polpa fria dos dedos dela, que esta mão respire como a minha, Ó Deus, e eu em paga deste sopro voarei me deitando ternamente sobre Teu corpo, [...] (p. 104).

O fluxo de pensamento de André é tão descontrolado que, no decorrer desse discurso, a personagem começa a erotizar a figura divina: 
[...] e caracóis incipientes e meigos na planície do Teu púbis, e uma penugem de criança há de crescer junto ao halo doce do Teu ânus sempre túmido de vinho; e tudo isso ressurgirá em Ti num corpo adolescente do mesmo milagre que as penas lisas e sedosas dos pássaros [...] (p. 105).

O discurso de André aqui apresentado é de chantagem e de tentativa de manipulação: ele tenta convencer e comprar a figura divina com suas palavras, oferecendo-lhe as melhores recompensas em troca da satisfação de suas pulsões - sugerindo o sacrifício de ovelhas em Seu nome, banquetes, vinho, prazeres carnais: "e Tua glória então nunca terá sido maior em toda a Tua história!” (p. 106). Fica clara, então, a característica manipuladora das palavras de André, o que leva a que se pense que Ana talvez não seja a pessoa descrita por André, que o mal estaria nele e não nela.

Essa mesma ideia de demonização das vítimas do sujeito perverso ocorre na obra de García Márquez, na qual Sierva María é associada ao demônio não somente por Cayetano, mas também pelas demais personagens. Tudo o que ocorre de negativo nos ambientes em que a menina está presente é culpa dela, pois ela traria a peste no corpo:

- Deixe-me - disse ela. - Não me toque. Delaura não ligou e ela soltou-lhe uma série de cusparadas na cara. Ele se manteve firme e lhe ofereceu a outra face. Sierva María continuou a cuspir. Ele tornou a mudar a face, embriagado pela onda de prazer proibido que lhe subiu das entranhas. Cerrou os olhos e rezou com a alma enquanto ela continuava a cuspir, tanto mais feroz quanto mais ele gozava, até que se deu conta da inutilidade de sua raiva. Então Delaura assistiu ao espetáculo pavoroso de uma verdadeira energúmena. A cabeleira de Sierva María se encrespou com vida própria, como as serpentes da Medusa, e de sua boca saiu uma baba verde, uma saraivada de impropérios em línguas de idólatras. Delaura brandiu o crucifixo, aproximou-o da cara dela e gritou aterrado: - Sai daí, sejas tu quem fores, besta dos infernos! (MÁRQUEZ, 1996, p. 176). 
A propósito do trecho que citamos, há uma série de questões que podem ser discutidas. Primeiro, o fato de que Sierva María está em um momento de crise, revoltada e arisca, dada a situação que ela tem enfrentado desde que foi internada no convento. Depois, o fato de que Cayetano não respeita o pedido da menina, de que não se aproxime, o que faz com que ele fique ainda mais irada e decidida a se defender do assédio, o que intensifica os sentimentos e o impulso à ação do padre. Quanto mais perturbados os seus sentidos, mais ele apela para a oração. Ao final, Sierva María é apresentada, pelo narrador - que, de certo modo, está contando a história a partir do foco de Cayetano - como um ser vindo do inferno, o que justificaria um exorcismo. As atitudes invasivas do padre em nenhum momento são associadas a algum rótulo negativo, como o que Sierva María recebe.

\section{$\mathrm{O}$ discurso religioso}

A linguagem humana é baseada nos diversos discursos recebidos e emitidos pelos falantes. O filósofo e linguista Mikhail Bakhtin (18951975) afirma em seus estudos, que todo signo linguístico carrega um símbolo e, consequentemente, uma ideologia. Para ele, "a palavra é o indicador de todas as mudanças sociais" (2002, p. 41), sendo um indicador de transformações ocorridas nas estruturas de convívio humano. Os signos vão fazendo sentido ao serem ligados, formando uma cadeia de símbolos que compõem as ideologias carregadas pelos discursos. São nos atos de fala que se localizam as mudanças, nas conversas de corredor, nos teatros e nas diversas reuniões sociais em que a língua está sendo utilizada pelo falante, que se encontra a importância da linguagem humana. Todo ser humano possui uma consciência individual que, segundo Bakhtin, "é um fato sócio-ideológico" (p. 53), ou seja, a consciência não deriva somente e diretamente das fontes naturais biológicas, como indicava o positivismo psicologista. A ideologia não vem de uma consciência acidental, mas sim das relações sociais da linguagem.

Todo discurso é orientado em relação ao interlocutor. Para Bakhtin: "O discurso citado é o discurso no discurso, a enunciação na enunciação, mas é, ao mesmo tempo, um discurso sobre o discurso, uma enunciação sobre a enunciação" (p. 144). Significa dizer que o discurso do falante é organizado tendo em vista seu interlocutor, ou seja, locutor e interlocutor, ou sua imagem, são responsáveis para a construção de sentido e, portanto, o primeiro automaticamente cita o segundo em seu discurso: 
Toda a essência da apreensão apreciativa da enunciação de outrem, tudo o que pode ser ideologicamente significativo tem sua expressão no discurso interior. Aquele que apreende a enunciação de outrem não é um ser mudo, privado da palavra, mas ao contrário um ser cheio de palavras interiores. Toda a sua atividade mental, o que se pode chamar o "fundo perceptivo", é mediatizado para ele pelo discurso interior e é por aí que se opera a junção com o discurso apreendido do exterior. A palavra vai à palavra. É no quadro do discurso interior que se efetua a apreensão da enunciação de outrem, sua compreensão e sua apreciação, isto é, a orientação ativa do falante. Esse processo efetua-se em dois planos: de um lado, a enunciação de outrem é recolocada no contexto de comentário efetivo (que se confunde em parte com o que se chama o fundo perceptivo da palavra); na situação (interna e externa), um elo se estabelece com a expressão facial, etc. Ao mesmo tempo, prepara-se a réplica (Gegenrede). Essas duas operações, a réplica interior e o comentário efetivo são, naturalmente, organicamente fundidos na unidade da apreensão ativa e não são isoláveis senão de maneira abstrata. Os dois planos da apreensão exprimem-se, objetivam-se no contexto narrativo que engloba o discurso citado (BAKHTIN, 2002, p. 147-148).

Considerando-se esses pressupostos, podemos dizer que, no que concerne ao discurso religioso, este se caracteriza como um discurso preparado para persuadir seu interlocutor a aceitar como válidos os princípios e valores que difunde, doutrinando-o a partir da manipulação via discurso, intencionalmente elaborado para este fim, utilizando estratégias manipuladoras. Tal fato pode ser evidenciado nas duas obras em destaque.

Em Lavoura Arcaica, os sermões utilizados pelo pai de André para pregação moral eram ouvidos e seguidos sem contestação por parte dos membros da família. As parábolas e as belas palavras escolhidas e proferidas eram aceitas e tomadas como lei dentro da casa. Com exceção de André, segundo o ponto de vista a que temos acesso, os irmãos e a mãe não notavam o grau de manipulação do discurso proferido pelo pai a cada refeição, responsável por ratificar, assim, sua posição de poder na 
274 | Eugenia Adamy Basso e Claudia Lorena Fonseca

instituição familiar. Tomando a conduta de seu pai como exemplo, adaptando-a para seus próprios fins, André também se utiliza do discurso moralista e religioso para tentar convencer Ana a ficar com ele, pois sabe que a religião é um fator muito importante onde vivem.

Neste contexto, em que falante e interlocutor interagem no momento mesmo da enunciação, há a prática da retórica, em que a arte da argumentação envolve o preparo do discurso para atrair o ouvinte:

De certa forma, podemos entender que todo discurso é persuasivo no sentido de buscar a adesão do seu auditório, e para isto concorrem as estruturas retóricas - meios de tirar ou colocar ênfase nos significados em função de opiniões ideológicas. A retórica está voltada para a comunicação persuasiva (PEÑA-ALFARO, 2005, p. 26).

Sabendo que, na situação em que se encontra, sua única arma é o discurso, André encontra Ana na capela e recorre a estratégias discursivas para conseguir a atenção da irmã:

[...] mas era inútil a minha prece, nenhuma vibração, sequer um movimento lhe sacudia o dorso [...]; mesmo assim em fui em frente, caroço por caroço, "Ana, me escute, é só o que te peço” eu disse forjando alguma calma, eu tinha de provar minha paciência, falar-lhe com a razão, falar-lhe com a razão, usar sua versatilidade, era preciso ali também aliciar os barros santos, as pedras lúcidas, as partes iluminadas daquela câmara, fazer como tentei na casa velha, aliciar e trazer para o meu lado toda a capela: "foi um milagre o que aconteceu entre nós, querida irmã [...]: as coisas vão mudar daqui pra frente, vou madrugar com nossos irmãos, seguir o pai para o trabalho [...] (NASSAR, 1999, p. 120).

O que se evidencia no trecho destacado, é que o irmão planeja, consciente dos seus atos, utilizar o contexto religioso em que se encontram, adaptando a ele seu discurso. Percebendo que as palavras de desespero que antes ele proferia não estavam convencendo a irmã, ele decide elaborar a fala com tom de tranquilidade e segurança, para que atingisse seu objetivo. Percebendo que Ana está na capela rezando, o irmão tenta convencer a irmã de que o que há entre eles é um milagre 
A intertextualidade e o discurso religioso no cindir do sujeito perverso | 275

divino. Por muitas páginas, o discurso de André incorpora elementos e valores fundamentais para a família da qual fazem parte, como o trabalho, o esforço coletivo e a união. Considerando-se que esses valores têm sua origem nos dogmas da fé católica e também nos princípios da fé muçulmana, parte-se para a obra de García Márquez, a fim de verificar como se apresenta sua situação de discurso no que diz respeito a esses aspectos.

Em Do amor e outros demônios, observamos que o pai de Sierva María há muito havia perdido a fé em Deus e na religião católica, o que o aproxima do médico ateu Abrenuncio, sendo influenciado, então, pelos princípios que norteiam a vida do médico. Porém, quando todos na cidade já estavam a par das notícias de que a filha do marquês vinha apresentando comportamento fora do que se considerava normal naquela sociedade, ou sinais de possessão demoníaca, segundo o entendimento geral, a notícia chega aos ouvidos do bispo local, que determina que esta seja internada no Convento das Clarissas, submetendo-a aos desígnios desta ordem, ou seja, retirando da família o poder de gerir seu destino, impedindo-os de buscar eles próprios a solução para os problemas identificados no comportamento de Sierva María. No entanto, para que a menina fosse internada, havia que convencer seu pai de que esta era a única solução possível. Para tanto, o bispo se vale do discurso, orientandoo no sentido de manipular sua consciência:

- É um segredo público que tua pobre filha rola pelo chão, tomada de convulsões obscenas e ladrando em gíria de idólatras. Não são sintomas inequívocos de uma possessão demoníaca?

O marquês estava espantado.

- Que quer dizer?

- Que entre as numerosas espertezas do demônio é muito frequente a de assumir a aparência de uma doença imunda para se introduzir num corpo inocente - disse. - E uma vez dentro, não há força humana que o faça sair (MÁRQUEZ, 1996, p. 84).

A princípio, o marquês não acredita que sua filha poderia ter qualquer vínculo com forças demoníacas, mas acaba por ser convencido e a envia para o tratamento a que seria submetida no intuito de supostamente curá-la. Mais uma vez, então, o destino de Sierva María é 
276 | Eugenia Adamy Basso e Claudia Lorena Fonseca

determinado pelo discurso manipulador daqueles que o detém para fins de exercício do poder.

\section{Considerações finais}

Na literatura, temas relacionados à perversão são recorrentes, a qual muitas vezes não é percebida como tal, sendo confundida com relações de amor entre as personagens. Isso ocorre porque a questão do perverso acaba sendo romantizada e, assim, assimilada. No entanto, é possível perceber sob a superfície do discurso outra camada, que revela aspectos interiores das personagens que certamente elas não desejam que venham à luz, por perturbadores e obscuros que são.

Na narrativa de Raduan Nassar, Lavoura Arcaica, André e Ana mantêm uma relação incestuosa, o que é inadequado moralmente e, principalmente, condenado pela doutrina religiosa da família. Na obra de García Márquez, Do amor e outros demônios, encontramos um caso que se configuraria como pedofilia, uma relação entre um padre e uma menina de doze anos que não se enquadra nos padrões de normalidade estabelecidos pela sociedade.

Podemos dizer que as duas obras escolhidas carregam características em comum: apresentam um discurso voltado para a manipulação sobretudo por personagens que apresentam traços de comportamento perverso, além de colocarem em cena personagens que estão divididas entre seguir os dogmas da religião que professam ou satisfazer seus desejos. Partindo do entendimento de que um texto se constitui de um universo de textos que previamente já foram acessados, o que aproxima as duas obras é sobretudo a forma empregada pelas personagens perversas na abordagem de suas vítimas - a manipulação via discurso - a fim de convencê-las, e ao leitor, e talvez inclusive a eles mesmos e à sociedade em que estão inseridos, de que elas são as culpadas por despertarem suas pulsões, pois estariam pactuadas com o demoníaco.

Outro aspecto que também é importante ressaltar é o papel do narrador em ambas as obras: em Lavoura Arcaica, há um narradorpersonagem em primeira pessoa, tendencioso e parcial, que tenta manipular o leitor, convencendo-o, muitas vezes. Em Do amor e outros demônios, o narrador se apresenta em terceira pessoa, o que o tornaria neutro em relação aos fatos narrados. Porém, esse narrador abre espaço para que Cayetano mescle sua voz a dele, privilegiando o ponto de vista do padre em relação ao de Sierva María, o que aproxima, também, as 
A intertextualidade e o discurso religioso no cindir do sujeito perverso | 277

duas narrativas. A abordagem de Cayetano a Sierva Maria é similar à de André em relação à Ana: convincentes e traiçoeiras. Sendo assim, é notável que o diálogo entre as obras seja forte: o discurso perverso e a religião aparecem para envolver o leitor, sendo o objetivo convencê-lo de que casos patológicos evidentes se tratam de amores proibidos.

\section{REFERÊNCIAS}

BAKHTIN, Mikhail. Marxismo e filosofia da linguagem. 9a ed. São Paulo: AnnaBlume, 2002.

CHIAPPINI, Ligia. O foco narrativo. 10 ed. São Paulo: Ática, 1985.

FERRAZ, Flávio Carvalho. Perversão. 5 ed. São Paulo: Casa do Psicólogo, 2010.

FREUD, Sigmund. Compêndio da psicanálise. Tradução de Renato Zwick. Porto Alegre: L\&PM, 2014.

FREUD, S. (1913). Totem e Tabu. In: FREUD, S. Edição standard brasileira das obras psicológicas completas de Sigmund Freud. v. 13. Rio de Janeiro: Imago, 1990, p. 11-125.

KRISTEVA, Julia. Poderes de la perversión. Buenos Aires: Siglo XXI editores, 2004.

MARQUES, Mariana. Afeto e sensorialidade no pensamento de B. Espinosa, S. Freud e D. W. Winnicott. Dissertação (mestrado) - Pontifícia Universidade Católica do Rio de Janeiro, Departamento de Psicologia, 2012. $135 \mathrm{f}$.

MÁRQUEZ, Gabriel García. Do amor e outros demônios. 9 ed. Rio de Janeiro: Record, 1996.

MASON, John. Olookun: Owner of Rivers and Seas. New York: Paperback, 1996.

NASSAR, Raduan. Lavoura arcaica. 3 ed. São Paulo: Companhia das Letras, 1999.

NITRINI, Sandra. Literatura comparada. São Paulo: EdUsp, 2010.

PEÑA-ALFARO, Alex. Estratégias discursivas de persuasão em um discurso religioso neopentecostal. Tese (doutorado) - Universidade Federal de Pernambuco, Programa de Pós-Graduação em Letras, 2005, $246 f$.

SAMOUYAULT, Tiphaine. Intertextualidade. São Paulo: Hucitec, 2008. ZILLES, Urbano. Filosofia da religião. São Paulo: Paulus, 2001. 
278 | Eugenia Adamy Basso e Claudia Lorena Fonseca

Conferência Episcopal Portuguesa. Celebração dos exorcismos. Disponível em: 〈http://www.liturgia.pt/rituais/Exorcismos.pdf>. Acesso em 14 set 2017.

Recebido em: 10/01/2018

Aceito em: 22/03/2018 